\title{
Analysis of the Effectiveness of the Application of Green Marketing to Typical Minang Restaurants with the Case of a Rumah Makan Sederhana Ringroad, Medan Branch
}

\author{
Vanessa Aulia Putri ${ }^{1}$, Sukaria Sinulingga ${ }^{2}$, Sugiharto Pujangkoro ${ }^{3}$ \\ ${ }^{1,2,3}$ Universitas Sumatera Utara, Indonesia. \\ Corresponding Author: Vanessa Aulia Putri
}

DOI: https://doi.org/10.52403/ijrr.20220229

\begin{abstract}
This study aims to find out and analysis of the effectiveness of the application of green marketing to typical Minang Restaurants with the case of a Rumah Makan Sederhana Ringroad, Medan Branch. This research is a causal descriptive study with a quantitative approach. This research was conducted at Rumah Makan Sederhana Ringroad, Medan Branch. The sample in this study amounted to 100 people obtained using judgment sampling. This research uses multiple linear regression technique which consists of $\mathrm{t}$ test and $\mathrm{F}$ test. The results obtained in this study indicate that green marketing are product, price, place, and promotion have a positive and significant effect on customer awareness.
\end{abstract}

Keywords: Green Marketing, Product, Price, Place, Promotion, Customer Awareness

\section{INTRODUCTION}

All green is a trend that exists today, starting from green products, green labels, green producers, green packaging, green business, green consumers, and also others. This has a very close relationship with environmental management issues that have become consumer demands for environmental sustainability and safety. The approach taken by business actors to maintain continuity in an activity by involving environmental care, which he knows as green business.
Not a few people are switching to using environmentally friendly products at this time to reduce the negative impact on the environment related to the issue of global warming. People who have awareness of the impact of global warming are commonly referred to as green consumers. This public awareness has made many producers of various products begin to switch back to using a variety of materials that cannot damage the environment and the term used is materials that are friendly to the environment. The materials he refers to are not only the raw materials for the product, but also the materials used to manufacture the product, such as labeling, packaging, wrapping, and so on.

Green consumers believe that there are real environmental problems today. This problem must be directly handled seriously enough and must be addressed in an active way, so that individuals can contribute regarding saving the earth from disasters on the environment (Smith, 1998). Natural conditions that have undergone various changes have an effect on changes in environmental conditions that are caused by none other than human activities that seem to ignore environmental problems.

Even now the problem of waste has become a problem that has not yet been resolved because the increase in the amount of existing waste is very difficult to predict 
and the level of difficulty in recycling the existing waste is very difficult. Plastic is one of the most difficult types of waste to recycle. Based on data obtained from the Central Statistics Agency (BPS), plastic waste in Indonesia amounts to 64 million tons every year. With a total of 3.2 million tons of which is a type of plastic waste that is thrown into the ocean. Then, the number of plastic bags that he disposes of in the environment is 10 billion pieces each year and an amount of 85 thousand tons by weight. This number puts Indonesia in the 2nd position as a country that has the largest or most polluted plastic waste into the sea.

The use of various kinds of green marketing tools such as eco-brands, ecolabels, and green advertising can be used to attract buying interest from customers who already understand the current state of the environment. In fact, not only can it attract buying interest from customers who already understand environmental conditions, the use of these green marketing tools can also be used to provide education to consumers who do not understand the current environmental conditions. These green marketing tools can be used as suggestions to make it easier for consumers to identify green products and even the use of these tools can also be used to raise awareness of green products. The application of these green marketing tools plays a major role in helping customers or prospective customers to distinguish non-green products from green ones and can change behavior rather than an actual purchase from customers who initially buy products on a non-green basis, then buy various kinds of products that are not green. friendly to the environment in order to reduce the adverse effects of using these products on the environment.

$\begin{array}{clcr}\begin{array}{c}\text { Byrne } \\ \text { environmental }\end{array} \text { marketing } & \text { states that } \\ \text { green }\end{array}$
marketing has become a new goal in business ventures, namely a planned marketing approach that has begun to emerge and has also attracted the attention of many parties starting from the end of the 20th century (Ottman, 1998). Conditions and situations like this require producers to be careful in making a policy on everything related to the environment. Attention to various kinds of environmental issues is evident from the increasing concern for the environment in the world market (Laroche et al., 2001).

Some fine dining restaurants may be hesitant to adopt new green initiatives because of concerns that consumers may have concerns about how these changes might affect them. The purpose of this research or research is to find out the intention of consumers to eat at luxury restaurants when new environmentally friendly practices are implemented, taking into account the influence of trust and perceived risk. Perceived risk significantly influences consumer consumption intentions.

Rumah Makan Sederhana is one of the restaurants that provides special food from the West Sumatra area. This restaurant serves a variety of West Sumatran specialties that are well known in Indonesian society. Rumah Makan Sederhana is one of the typical Padang restaurants which is growing rapidly in Indonesia. Until now, there are more than 100 branches of Rumah Makan Sederhana s in Indonesia. Rumah Makan Sederhana is also a pioneer or a pioneer from the Padang restaurant which for the first time has the most branches covering almost all cities in Indonesia with ownership which is only owned by the same person. This restaurant does not only serve food menus such as rendang, but there are quite a lot of varied food choices provided by this restaurant, such as sate padang, soto padang, dendeng balado, curry head snapper and so on. The various choices of food menus in this restaurant have a taste that is not inferior to rendang and the taste of the food is very different from other Padang restaurants. This Rumah Makan Sederhana has a taste of food that is quite delicious and can be accepted by all customers who come to it.

Rumah Makan Sederhana as one of the leading restaurants in Indonesia feels the 
need to participate in the implementation of green marketing. The application of green marketing will help reduce the negative impact of global warming. The coronation of rendang as the most delicious food in the world by CNN had a good impact on sales at Rumah Makan Sederhana. However, this increase in sales has resulted in an increase in the use of non-recyclable goods by Rumah Makan Sederhana and its customers. Until now, plastic-based products are still used by Rumah Makan Sederhana, including those used for packaging take away food, straws, drink cups for juice, plastic for wrapping water, plastic spoons and forks for take away customers.

This study aims to find out and analysis of the effectiveness of the application of green marketing typical Minang Restaurants with the case of a Rumah Makan Sederhana Ringroad, Medan Branch.

\section{RESEARCH METHODS}

This research is a causal descriptive study with a quantitative approach. Causal descriptive study is a research procedure that can be used by researchers to investigate possible causal relationships in a way based on observations of existing effects looking for factors that may be the cause through certain data (Pandiangan et al., 2021). This is in contrast to experimental methods which collect data at the present time under controlled conditions (Pandiangan, 2015). Quantitative approach is an approach that in research proposals, processes, hypotheses, goes to the field, analyzes data and concludes data until the writing uses aspects of measurement, calculation, formulas and certainty of numerical data (Pandiangan, 2018). Quantitative research uses instruments (data collection tools) that produce numerical data (numbers). Data analysis was carried out using statistical techniques to reduce and group data, determine relationships and identify differences between groups of data (Pandiangan et al., 2018).
This research was conducted at Rumah Makan Sederhana Ringroad, Medan Branch.

The sample in this study amounted to 100 people obtained using judgment sampling.

This research uses multiple linear regression technique which consists of t test and $\mathrm{F}$ test. Multiple linear regression, also known simply as multiple regression, is a statistical technique that uses several explanatory variables to predict the outcome of a response variable. Multiple regression is an extension of linear (OLS) regression that uses just one explanatory variable (Tobing et al., 2018).

\section{RESULT \\ Descriptive Analysis of Respondents Characteristics}

The research was conducted quantitatively by distributing questionnaires to 100 customers of Rumah Makan Sederhana Ringroad, Medan Branch who understand green marketing. The questionnaire made by the researcher consisted of 5 variables with a total of 14 statements. Characteristics of respondents is the identity of the respondents who became the research sample.

Based on data, information is obtained that the majority of respondents from this study were women, as many as 56 people or $56 \%$. Male respondents in this study amounted to 44 people or $44 \%$.

Based on data, information is obtained that the majority of respondents from this study were dominated by the age range of 23-28 years as many as 36 people or 36\% and respondents aged 29-34 years as many as 25 people or $25 \%$.

Based on data, information is obtained that $51 \%$ or 51 of the respondents have an undergraduate education background, as many as $23 \%$ or 23 of the respondents have a high school education background, $14 \%$ or 14 people have a Diploma Education background and the remaining 12 people or $12 \%$ have an educational background of S2. 
Based on data, information is obtained that $29 \%$ or 29 of the respondents in this study are private employees. 20 people or $20 \%$ are students, 14 people or $14 \%$ are entrepreneurs, 13 people or $13 \%$ are BUMN employees, 9 people or $9 \%$ are civil servants, 7 people or $7 \%$ are housewives, 6 people or $6 \%$ are TNI/Polri, 1 person or $1 \%$ is a pharmacist and 1 other person or $1 \%$ does not mention the type of work.

Based on data, information is obtained that the respondents from this study are dominated by people who have an income $>\mathrm{Rp} 3,500,000$, namely 66 people or $66 \%$ of the sample. $18 \%$ of the sample of this study or as many as 18 people have incomes ranging from $\mathrm{Rp} 1.000 .000$ $\mathrm{Rp} 3,000,000$, and $16 \%$ of the sample of this study or as many as 16 people have income $<$ Rp1,000,000.

Based on data, information is obtained that as many as 42 people or $42 \%$ of the total sample have bought 5 times, 38 people or $38 \%$ of the total sample have bought 6-10 times, and as many as 20 people or $20 \%$ of the sample of this study have purchased $>10$ times.

\section{Simultaneous Significance Test (F Test)}

The $\mathrm{F}$ test aims to examine the effect of the independent variables together or simultaneously on the dependent variable of customer awareness.

Table 1. F Test of Results

\begin{tabular}{|c|c|c|c|c|c|c|}
\hline \multicolumn{7}{|c|}{ ANOVA } \\
\hline \multicolumn{2}{|c|}{ Model } & Sum of Squares & df & Mean Square & F & Sig. \\
\hline \multirow{2}{*}{1} & Regression & 18.160 & 4 & 4.540 & 17.461 & $.000^{\mathrm{a}}$ \\
\cline { 2 - 7 } & Residual & 24.700 & 95 & .260 & & \\
\cline { 2 - 7 } & Total & 42.860 & 99 & & & \\
\hline
\end{tabular}

Based on Table 1, it is known that the calculated F value is 17.461 and the Sig value. is 0.000 . It is known that the calculated $\mathrm{F}$ value is $17.461>\mathrm{F}$ table 2.467 and the sig value is $0.000<0.05$, then green product, green price, green place, green promotion together or simultaneously has a significant effect on customer awareness.

\section{Partial Significance Test (t Test)}

Statistical $t$ test was used to determine the level of significance of the effect of each independent variable on the dependent variable. Table 2 presents the value of the regression coefficient, as well as the value of the $t$ statistic for partial effect testing.

Table 2. $t$ Test of Results

\begin{tabular}{|c|c|c|c|c|c|c|c|c|}
\hline \multicolumn{9}{|c|}{ Coefficients $^{\mathrm{a}}$} \\
\hline \multirow{2}{*}{\multicolumn{2}{|c|}{ Model }} & \multicolumn{2}{|c|}{ Unstandardized Coefficients } & \multirow{2}{*}{$\begin{array}{c}\text { Standardized Coefficients } \\
\text { Beta }\end{array}$} & \multirow[t]{2}{*}{$\mathbf{t}$} & \multirow[t]{2}{*}{ Sig. } & \multicolumn{2}{|c|}{ Collinearity Statistics } \\
\hline & & B & Std. Error & & & & Tolerance & VIF \\
\hline \multirow[t]{5}{*}{1} & (Constant) & -.319 & .565 & & -.564 & .574 & & \\
\hline & Product $\left(\mathrm{X}_{1}\right)$ & .332 & .076 & .348 & 4.345 & .000 & .946 & 1.057 \\
\hline & Price $\left(\mathrm{X}_{2}\right)$ & .201 & .082 & .207 & 2.456 & .016 & .854 & 1.171 \\
\hline & Place $\left(\mathrm{X}_{3}\right)$ & .304 & .088 & .285 & 3.439 & .001 & .882 & 1.134 \\
\hline & Promotion $\left(\mathrm{X}_{4}\right)$ & .262 & .125 & .179 & 2.096 & .039 & .835 & 1.198 \\
\hline
\end{tabular}

The results obtained in this study indicate that green marketing are product, price, place, and promotion have a positive and significant effect on customer awareness.

\section{CONCLUSION AND SUGGESTION}

The results obtained in this study indicate that green marketing are product, price, place, and promotion have a positive and significant effect on customer awareness.

The suggestions in this research are:

1. Reduce the use of single-use items and other materials that are not easy to decompose naturally.

2. To save costs as much as possible so that later the results of these savings can be used to meet the needs of producing green products. 
3. To standardize procurement activities, production processes, and services to customers in an effort to save on the use of resources (electricity, water, and human labor).

4. Maximizing promotional activities online through social media platforms such as websites, Instagram, Facebook, and others. Not only promotion of products, but also promotion of green activities that have been carried out at this restaurant.

\section{Acknowledgement: None}

\section{Conflict of Interest: None}

\section{Source of Funding: None}

\section{REFERENCES}

1. Byrne, Michael. (2002). Understanding Consumer Preferences Across Environmental Marketing Mix Variations. OIKOS University of Newcastle.

2. Laroche, M., J. Bergeron, G. BarbaroForleo. (2001). Targeting Consumers Who Are Willing to Pay More for Environmentally Friendly Products. Journal of Consumer Marketing, 18(6), 503-520.

3. Ottman, J.A., et al., 1998. Green Marketing Myopia : Ways to Improve Consumer Appeal for Environmentally Preferable Products. Environment Volume 48, Number 5 pp. 22-36. Heldref Publications.

4. Pandiangan, Saut Maruli Tua. (2015). Analisis Lama Mencari Kerja Bagi Tenaga Kerja Terdidik di Kota Medan. Skripsi. Medan: Fakultas Ekonomi dan Bisnis, Program Studi Ekonomi Pembangunan, Universitas Sumatera Utara. https://www.academia.edu/52494724/Analis is_Lama_Mencari_Kerja_Bagi_Tenaga_Ker ja_Terdidik_di_Kota_Medan.

5. Pandiangan, Saut Maruli Tua. (2018). Analisis Faktor-faktor yang Mempengaruhi Penawaran Tenaga Kerja Lanjut Usia di Kota Medan. Tesis. Medan: Fakultas
Ekonomi dan Bisnis, Program Studi Ilmu Ekonomi, Universitas Sumatera Utara. http://repositori.usu.ac.id/bitstream/handle/1 23456789/10033/167018013.pdf?sequence= 1\&isAllowed $=\mathrm{y}$.

6. Pandiangan, Saut Maruli Tua, Rujiman, Rahmanta, Tanjung, Indra I., Darus, Muhammad Dhio, \& Ismawan, Agus. (2018). An Analysis on the Factors which Influence Offering the Elderly as Workers in Medan. IOSR Journal of Humanities and Social Science (IOSR-JHSS), 23(10), 76-79. DOI: $\quad 10.9790 / 0837-2310087679$. http://www.iosrjournals.org/iosrjhss/papers/Vol.\%2023\%20Issue10/Version $-8 /$ K2310087679.pdf.

7. Pandiangan, Saut Maruli Tua, Resmawa, Ira Ningrum, Simanjuntak, Owen De Pinto, Sitompul, Pretty Naomi, \& Jefri, Riny. (2021). Effect of E-Satisfaction on Repurchase Intention in Shopee User Students. Budapest International Research and Critics Institute-Journal, 4(4), 77857791.

DOI: https://doi.org/10.33258/birci.v4i4.2697.

8. Smith, T. M. (1998). The My Thof Green Marketing: Tending Our Goats at the Edge of Apocalypse. Toronto: University of Toronto Press.

9. Tobing, Murniati, Afifuddin, Sya'ad, Rahmanta, Huber, Sandra Rouli, Pandiangan, Saut Maruli Tua, \& Muda, Iskandar. (2018). An Analysis on the Factors Which Influence the Earnings of Micro and Small Business: Case at Blacksmith Metal Industry. Academic Journal of Economic Studies, 5(1), 17-23. https://www.ceeol.com/search/articledetail $? \mathrm{id}=754945$.

How to cite this article: Vanessa Aulia Putri, Sukaria Sinulingga, Sugiharto Pujangkoro. Analysis of the effectiveness of the application of green marketing to typical minang restaurants with the case of a Rumah Makan Sederhana Ringroad, Medan Branch. International Journal of Research and Review. 2022; 9(2): 204-208. DOI: https://doi.org/10.52403/ijrr.20220229 